\title{
Biopesticides in Sustainable Agriculture: A Critical Sustainable Development Driver Governed by Green Chemistry Principles
}

\author{
Emmanuel O. Fenibo ${ }^{1 *}$, Grace N. ljoma ${ }^{2}$ and Tonderayi Matambo ${ }^{2}$ \\ ${ }^{1}$ World Bank Africa Centre of Excellence, Centre for Oilfield Chemical Research, University of Port Harcourt, Port Harcourt, \\ Nigeria, ${ }^{2}$ Institute for the Development of Energy for African Sustainability, University of South Africa, Roodepoort, \\ South Africa
}

Keywords: biopesticides, environmental stewardship, green chemistry, SDGs, sustainable agriculture

\section{INTRODUCTION}

The application of conventional pesticides is underscored by many negative externalities including environmental degradation and pest resistance. Consequently, their use in commercial farming is attracting regulatory restrictions leading to $2 \%$ decline per year in synthetic pesticides use in favor of $10 \%$ increase of biopesticides as alternative agrochemicals (Damalas and Koutroubas, 2018).

\section{OPEN ACCESS}

Edited by:

Johann G. Zaller,

University of Natural Resources and

Life Sciences, Austria

Reviewed by:

Jayanta Kumar Patra,

Dongguk University, South Korea

Suprasanna Penna,

Bhabha Atomic Research Centre

(BARC), India

*Correspondence:

Emmanuel O. Fenibo

feniboe1478@gmail.com

Specialty section:

This article was submitted to Agroecology and Ecosystem Services,

a section of the journal

Frontiers in Sustainable Food Systems

Received: 19 October 2020

Accepted: 06 April 2021

Published: 11 June 2021

Citation:

Fenibo EO, ljoma GN and Matambo T (2021) Biopesticides in Sustainable Agriculture: A Critical Sustainable Development Driver Governed by Green Chemistry Principles. Front. Sustain. Food Syst. 5:619058. doi: 10.3389/fsufs.2021.619058 Microbial biopesticides, biochemical biopesticides, and plant-incorporated protectants (PIPs) are the well-known categories of biopesticides, and they command 5\% share of the pesticide global market, with microbial biopesticide taking the lead (Pathma et al., 2021). However, the complete adoption of biopesticides is hindered by the short supply of products to meet farmers' demands, high cost of refined products, and slow action that they mostly exhibit (Verma et al., 2021). Although, these drawbacks are balanced with the tolerable toxicity, if any, that is manifested by biopesticides. They are also biodegradable, specific in action (harmless to non-target organisms), and also possess the ability to counter pest resistance issues caused by synthetic pesticides (Mishra et al., 2020). In the meantime, as the world waits for research advances to address the drawbacks, presently, crude extracts of pesticidal plants can be relied on, especially for local farmers and developing countries. Biopesticide-driven sustainable agriculture enjoys social acceptability, promotes economic productivity, and engenders environmental stewardship. These three dimensions represents the tripartite concept of sustainable development whose finest concept is currently contained in the United Nations 2030 agenda, popularly known to as the Sustainable Development Goals (SDGs).

The SDGs tend to address all-round development including hunger eradication, poverty reduction, and sustainable farming among others (Vetter et al., 2017). Sustainable agriculture serves as the most critical sector of the SDGs, and it integrates most aspect of the 17 SDGs, directly and indirectly. However, it is directly linked to eight of the 17 SDGs in which both the SDG2 (Zero Hunger) and SDG1 (No Poverty) exert the greatest influence, while SDG9 (innovative technology and infrastructure) and SDG7 (affordable energy) have the least influence based on the decreasing degree of reliance on agriculture. The goals of these eight SDGs are centered on sustainable production and utilization, reliance on biodegradable feedstock, and environmental protection, which are to some extent the goals of green chemistry (GC) principles. As green agrochemicals, biopesticides have great influence in sustainable agriculture, because their characteristics satisfy the conditions of GC principles and the tripartite concept of sustainable development. Moreover, this interconnectedness of sustainable development and GC by biopesticide-driven commercial farming ensures environmental protection, quantitative and qualitative productivity, safe and effective technology, and judicious and effective use of resources. 


\section{DEFINITION AND CATEGORIES OF BIOPESTICIDES}

Biopesticides are competitive subclass of pesticides that are naturally occurring organisms or compounds that suppress the growth and proliferation of pests' population by diverse mechanisms of action, excluding those that interfere with pests' nervous systems (Tijjani et al., 2016; Marrone, 2019; Nuruzzaman et al., 2019; Wattimena and Latumahina, 2021). They are categorized into three groups: microbial biopesticides, biochemical biopesticides, and PIPs (Leahy et al., 2014; Liu et al., 2019; Ram and Singh, 2021). Bacillus thuringiensis (Bt) control $90 \%$ of the microbial biopesticide market; however, Beauveria bassiana, Baculovirus, Steinernema, Nosema, and Chlorella have also demonstrated significant roles (Steinkraus and Tugwell, 1997; Abu-Dieyeh and Watson, 2007; Radwan et al., 2018; Gonçalves, 2021). Biochemical biopesticides are compounds (or exact synthetic analog) of natural origin possessing active ingredients that control pest by mechanisms that are nontoxic to the target pest, the environment and humans (Kumar, 2012; Reddy and Chowdary, 2021). Examples include essential oil, semiochemicals, plant growth-promoting regulators, insect growth regulators, secondary metabolites, and natural minerals (Ghongade and Sangha, 2021; Singh et al., 2021). PIPs are transgenic plants that render the plant unsuitable for pest attack. Insecticidal molecules employed in PIP technology are Bt Cry proteins, toxic complex (Tc) proteins from Xenorhabdus and Photprhabdus, $\alpha$-amylase inhibitors, protease from Baculovirus, double-stranded ribonucleic acid (dsRNA), and Mir1-CP from maize (Shingote et al., 2013; Maciel et al., 2014; Parker and Sander, 2017; Wei et al., 2018; Ganapathy et al., 2021).

\section{ADVANTAGES OF BIOPESTICIDES}

Biopesticides exert their inhibitory effects through multiple mode of actions such as growth regulators, gut disruptors, metabolic poison, neuromuscular toxins, and non-specific multisite inhibitors (Sparks and Nauen, 2015; Dar et al., 2021). These multiple modes of action against targeted pests obliterate the chances of developing resistance as is common with chemical pesticides. The intensive use of conventional pesticides in industrial-scale farming over a long period, especially in the Green Revolution era, also created challenges such as pesticide-related pollution, post-harvest chemical consumption through bioaccumulation, biodiversity losses, and insurgence of secondary pests and elimination of natural/beneficial enemies. These negative consequences are not associated with the use of biopesticides. Thus, prohibitive restrictions are continually imposed on synthetic pesticides to reduce their numbers with time. For instance, there has been a reduction to 250 active ingredients of conventional pesticides in 2009 as opposed to more than 1,000 in 2001 while entrance of new conventional pesticides into the market reduced from 70 in 2000 to 28 in 2012 (McDougall, 2013). The direct result of the declining number of classical pesticides is the increased demand for biopesticides for some beneficial reasons. These benefits include, but are not exclusive to, altering the course of pest resistance, low toxicity properties, complementary input to synthetic pesticides, ecofriendliness, specificity (thus have little or no negative impact on non-target organisms and humans), biodegradability, and little or no problem of post-harvest contamination, stability against abiotic stress (Deravel et al., 2014; Kalpana and Anil, 2021), and compatibility in integrated pest management (IPM).

\section{PROSPECTS AND LIMITATION OF BIOPESTICIDES}

In the nearest future, biopesticides could replace synthetic pesticides without significantly affecting productivity and yield, if their potentials are fully maximized (Mishra et al., 2020). The limitation confronting the full adoption of biopesticides are the high cost of refined commercial products, inability to meet global market demand, differing standard method of preparations and guidelines, dose determination of active ingredients, the susceptibility of biopesticides to several environmental factors, ephemeral stability, and slow action among others. While expecting these limitations to be addressed through research breakthroughs in the coming years, farmers, especially in rural areas, can take advantage of a crude plant extract in protecting plants for improved yield (Stevenson et al., 2017). The effectiveness of the application of pesticides, including biopesticides, is maximal when incorporated in IPM (Quarles, 2013). An IPM is a pest-control option, equivalent to an effective multi-faceted approach involving the combination of cultural practices and other suitable control tactics into one management program to achieve a long-lasting reduction of pest population and associated problems (Sadof et al., 2021). Positive externalities that go along with biopesticides besides significant pest population reduction are social acceptability, economic viability, and environmental stewardship, the threedomain concept of sustainable development.

\section{BIOPESTICIDES AS DRIVERS OF SUSTAINABLE AGRICULTURE AND SUSTAINABLE DEVELOPMENT}

As with other natural resources, such as biostimulators and biofertilizers, biopesticide application in mechanized farming creates a balance amongst sociocultural relevance, economic productivity, and environmental protection that is considered pivotal to sustainable agriculture. Integration of public policy into these four domains (technology inclusive) would yield a much higher concept known as sustainable development (Marteel-Parrish and Newcity, 2017; Adhikari et al., 2020). The most current strategies aimed at achieving sustainable development are contained in the United Nations 2030 Agenda (17 SDGs). Sustainable agriculture is one practical sector that connects to all the SDGs but directly linked to eight out of the 17 goals. Biopesticide-driven sustainable agriculture can reduce poverty (SDG1: No Poverty) and address hunger (SDG2: Zero Hunger). Stewardship of the natural resources is required for the continuous exploitation of the environment for 
agricultural productivity (SDG6: Clean Water and Sanitation, SDG12: Sustainable Consumption and Production, SDG14: Life Under Water and SDG15: Life on Land). Furthermore, sustainable agriculture requires energy (SDG7: Affordable Energy), technology, and innovation (SDG9).

\section{GREEN CHEMISTRY IN SUSTAINABLE AGRICULTURE AND SDGs}

GC most critical concept is that of design, and it aims to achieve sustainability at the very molecular level (Ahluwalia and Kidwai, 2004; Anastas and Eghbali, 2010). As a result, GC covers a wide range of fields including agriculture. The direct connection of sustainable agriculture in the SDGs is dependent on the immediate positive impact of agriculture, judicious use and conservation of critical resources, application of green agro-products, sustainable technology and green energy, or the combination of any two or more of these. The use of green agro-products can influence SDG2 and SDG1, while SDG6, SDG12, SDG14, and SDG15 can be influenced by conservation principles, environmental sustainability, and judicious use of critical resources. These goals are reflected in GC, which aims to mitigate harmful chemicals from production down to application, process safety, optimal energy consumption, and improved economy (Tickner et al., 2021). The two priority massbased metrics upon which the GC partly rest on are atomic economy (AE) and environmental impact factor (E factor). The $\mathrm{AE}$ measures the content of reactants present in the final products (Koulougliotis et al., 2021) while the E factor measures the waste amount in $1 \mathrm{~kg}$ mass of the target product, exempting water (Hechelski et al., 2021). In the context of GC, the higher the $\mathrm{AE} /$ lesser $\mathrm{E}$ factor, the better for the sustainability goals affiliated with agriculture. The pursuit of ideal AE (100\%) and E factor (0) in the production of a target chemical product demands $100 \%$ resource efficiency: mass of reactants $=$ mass of target products (Glavic et al., 2021). Beyond mass-based metrics is the life-cycle assessment, which comprehensively considers factors such as process input (reagents, solvents, metals) sustainability, environmental impact (carbon footprint, energy consumption, eco-toxicity, risk factor), implicated material/products (Sheldon, 2017; Sukumaran and Gopi, 2021), and analytical methods that work on the concept of minimized hazards and solvents, operator safety maximization, device and sample miniaturization, and greener solvent usage (Panhwar et al., 2021). These metrics are covered under the 12 principles of GC.

GC and its 12 principles can play a useful role in defining the concept of sustainability in six of the highlighted eight SDGs. Though the 12 principles are more oriented to the chemical process at the bench scale, they can still be linked to agriculture (Gałuszka et al., 2013; Abdussalam-Mohammeda et al., 2020) with efficient utilization of renewable resource and waste elimination as the most influential dimensions (Sheldon, 2017). The 12 principles of the GC and their relatedness to the eight SDGs (with SDG7 and SDG9 as input) is depicted in Figure 1. Agricultural yields will effectively increase at the lowest cost when pests are controlled using biopesticides following the sequence of the eight IPM principles outlined in ANNEX III of the Framework Directive 2009/128/EC (Barzman et al., 2015), which are prevention and suppression, monitoring, decision-making, non-chemical methods, pesticide selection, reduced pesticide use, antiresistance strategies, and evaluation. These principles, largely, are geared toward cost-effectiveness, enhanced productivity, environmental protection, process safety, sustainable production, and consumption.

\section{DISCUSSION}

Biopesticides are safer pest control chemicals, mostly derived from a natural resource (GCP7: use of renewable feedstock). In their purest forms, they have a high AE (GCP2) and low E factor (GCP1: prevent waste). This implies that the majority of the starting chemical species are reflected in the final products. Botanical biopesticides are characterized by wastes originating from the primary materials (Jessop et al., 2008). In this sense, the final product has lower resource efficiency: low $\mathrm{AE}$ and high $\mathrm{E}$ factor. However, the wastes are resourceful since they can be used for farmland improvement through compost manuring, pathogen suppression, and soil bioremediation (Rai et al., 2021; Tyagi and Kumar, 2021). These secondary advantages coupled with direct benefits of biopesticides (stated earlier) will lead to sustainable agriculture: increase of agro-yield, improving environmental safety, and socio-cultural acceptability. As an agro-chemical, biopesticides are unique for being biodegradable (GCP10) and have a low $\mathrm{E}$ factor, thus meeting the criterion of a safer chemical (GCP4). However, to achieve maximum benefits inherent in GC, deliberate measures are taken during the production process: employment of green technology [through the combination of less hazardous chemical synthesis (GCP3), use of safer solvent and auxiliaries (GCP5), reduce derivatives (GCP8), catalysis (GCP9), and inherent safety processes (GCP12)].

GC Principle 4 and 10 define biopesticide characteristics; Principles 3, 5, 8, and 9 govern greener production; while Principle 12 governs a safe production procedure. Principle 6 is concerned with an efficient and judicious use of energy achieved through catalysis, solventless reactions, synthetic photochemistry, and microwave-assisted synthesis (Jessop et al., 2008; Kharissova et al., 2019). Attributes of sustainable agriculture include but not exclusive to the application of green chemicals (GCP4, 7, 8, and 10), environmental conservation (GCP1, 2, and 11), judicious use of natural resources, and employment of safer (GCP3, 5, 8, 9, and 12) technology (Sheldon, 2017; Tickner et al., 2021). Correspondingly, these attributes are also linked to SDGs that are directly linked to sustainable agriculture. The green agro-product is linked to productivity (SDG1 and SDG2); judicious use of resources is linked to SDG12; and conservation attribute is linked to SDG6, SDG14, and SDG15; while innovative technology (SDG9) and affordable energy (SDG7) inputs contribute to productivity. From the foregoing, it is evident 


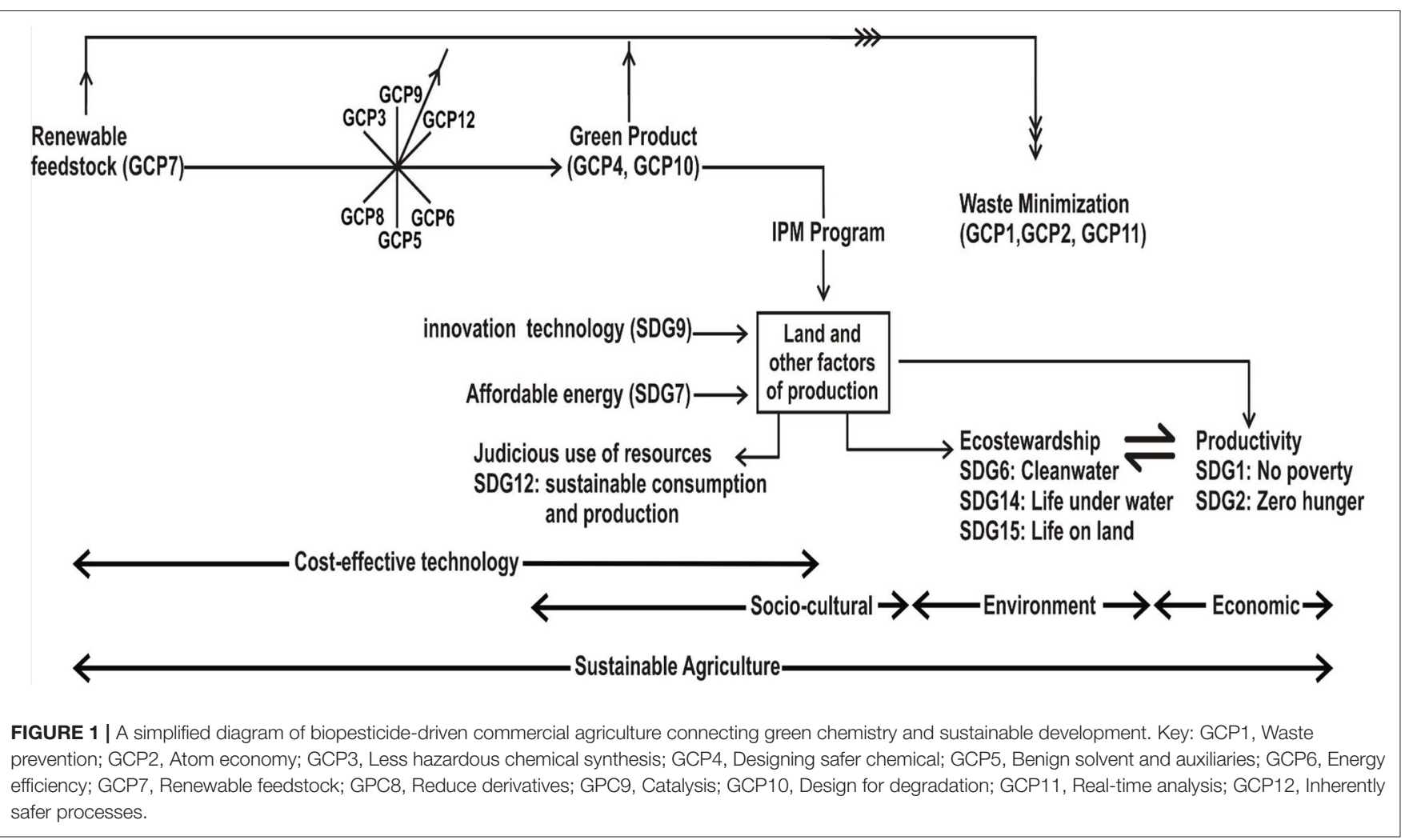

that GCP7 is the most critical resource for biopesticides, whose improvement lies in green technology and research breakthrough. Thus, priority attention on GCP7, green technology, and constructive human actions (policies and leadership) can lead to sustainable agriculture defined by agricultural productivity, environmental sustainability, and socio-cultural acceptability.

Biopesticide-driven agriculture shows to link GC and sustainable development on four dimensions: (1) environmental safety, (2) judicious use of resource, (3) productivity, and (4) safety/cost effective technology. Environmental safety connects GCP1, 2, 11 with SDG6, 14, 15, while judicious use of resources links GCP6, 7, and SDG12. The third dimension, productivity, connects GCP4, 10 with SDG1 and 2, while the last dimension, safety/cost-effective technology, connects GCP1, 2, 3, 8, 9, 12 with SDG7, 9. Overall, biopesticides from a GC perspective are intricately connected to renewable feedstock (GCP7), green product $(\mathrm{GCP} 4,10)$, waste minimization (GCP1, 2, 11), energy efficiency (GCP6, GCP9), and process safety (GCP12). When applied in large-scale farming driven by innovative technology (SDG9) and affordable energy (SDG7), sustainable agriculture is defined, which is characterized by increased productivity (SDG1, SDG2), environmental sustainability, and conservation (SDG6, SDG12, SDG14, SDG15) and socio-cultural acceptability. However, the relevance of the SDGs to sustainable agriculture is in the following order: SDG2 > SDG1 > SDG15 > SDG14 > SDG12 > SDG6 > SDG9 > SDG7, while the most dominant GC principles that guide biopesticide-driven agriculture are an efficient use of renewable feedstock and waste elimination.

Overcoming what currently seems to be obstacles to the full adoption of biopesticides in agriculture require research breakthroughs that would ensure efficiency in production, formulation, and packaging of formulated products as critical processes of biopesticide commercialization. Additionally, nanotechnology knowledge will be required for formulations, genetic material delivery into crops, controlled release, detection of pesticides and pathogens, improving the stability and encapsulation of (bio)pesticides (Manchikanti, 2019). As interest in nanobiopesticides increases, equal attention should be paid to biosurfactants that have pesticidal significance because microorganisms that produce these multi-functional molecules can also serve as biofertilizers (Kulkarni et al., 2007; Sarwar et al., 2018; Fenibo et al., 2019; De Oliveira, 2021). Further, omics technology such as recombinant DNA techniques and proteomics would be required for the elucidation of novel toxins discovery (Nakasu et al., 2014; Sarethy and Saharan, 2021; Trivedi et al., 2021). Sequencing technology is critical for strain selection during bioprocessing of active microbial agent and insecticidal gene targeting (Glare and Moran-Diez, 2016; Peralta et al., 2021). More so, drone technology (Sujayanand et al., 2021) regulatory protocols, incentives from government and education are needed to make biopesticides products cost-friendly and favorably substitute synthetic pesticides with the attendant positive externalities, including crop productivity and environmental protection. 


\section{AUTHOR CONTRIBUTIONS}

EF wrote the manuscript. GI carried out the initial review. TM developed the concept and did the final review. All authors contributed to the article and approved the submitted version.

\section{REFERENCES}

Abdussalam-Mohammeda, A., Alia, A. Q., and Errayes, A. O. (2020). Green chemistry: principles, applications, and disadvantages. Chem. Methodol. 4, 408-423. doi: 10.33945/SAMI/CHEMM.2020.4.4

Abu-Dieyeh, M. H., and Watson, A. K. (2007). Efficacy of Sclerotinia minor for dandelion control: effect of dandelion accession, age and grass competition. Weed. Res. 47, 63-72. doi: 10.1111/j.1365-3180.2007.00542.x

Adhikari, K., Bhandari, S., Niraula, D., and Shrestha, J. (2020). Use of neem (Azadirachta indica A. Juss) as a biopesticide in agriculture: a review. J. Agric. Appl. Biol. 1, 100-117. doi: 10.11594/jaab.01.02.08

Ahluwalia, V. K., and Kidwai, M. (2004). "Basic principles of green chemistry," in New Trends in Green Chemistry (Dordrecht: Springer).

Anastas, P., and Eghbali, N. (2010). Green chemistry: principles and practice. Chem. Soc. Rev. 39, 301-312. doi: 10.1039/B918763B

Barzman, M., Barberi, P., Birch, A. N. E., Boonekamp, P., Dachbrodt-Saaydeh, S., Graf, B., et al. (2015). Eight principles of integrated pest management. Agron. Sustain. Dev. 35, 1199-1215. doi: 10.1007/s13593-015-0327-9

Damalas, C. A., and Koutroubas, S. D. (2018). Current status and recent developments in biopesticide use. Agriculture 8:13. doi: 10.3390/agriculture8010013

Dar, S. A., Wani, S. H., Mir, S. H., Showkat, A., Dolkar, T., and Dawa, T. (2021). Biopesticides: mode of action, efficacy and scope in pest management. J. Adv. Res. Biochem. Pharmacol. 4, 1-8.

De Oliveira, J. L. (2021). "Nano-biopesticides: present concepts and future perspectives in integrated pest management," in Advances in Nano-Fertilizers and Nano-Pesticides in Agriculture, eds S. Jogaiah, H. Singh, L. Fernandes, and F. R. Lima (Cambridge: Woodhead Publishing), 1-27.

Deravel, J., Krier, F., and Jacques, P. (2014). Biopesticides, a complementary and alternative approach to the use of agrochemicals. A review. Biotech. Agro Soc. Environ. 18, 220-232.

Fenibo, E. O., Ijoma, G. N., Selvarajan, R., and Chikere, C. B. (2019). Microbial surfactants: the next generation multifunctional biomolecules for applications in the petroleum industry and its associated environmental remediation. Microorganisms 7:581. doi: 10.3390/microorganisms7110581

Gałuszka, A., Migaszewski, Z., and Namieśnik, J. (2013). The 12 principles of green analytical chemistry and the significance mnemonic of green analytical practices. Trends Analyt. Chem. 50, 78-84. doi: 10.1016/j.trac.2013.04.010

Ganapathy, S., Parajulee, M. N., San Francisco, M., Zhang, H., and Bilimoria, S. L. (2021). Novel-iridoviral kinase induces mortality and reduces performance of green peach aphids (Myzus persicae) in transgenic Arabidopsis plants. Plant Biotechnol. Rep. 15, 13-25. doi: 10.1007/s11816-020-00659-w

Ghongade, D. S., and Sangha, K. S. (2021). Efficacy of biopesticides against the whitefly, Bemisia tabaci (Gennadius) (Hemiptera: Aleyrodidae), on parthenocarpic cucumber grown under protected environment in India. Egypt. J. Biol. Pest Control. 31, 1-11. doi: 10.1186/s41938-021-00365-x

Glare, T. R., and Moran-Diez, M. E. (eds.). (2016). Microbial-Based Biopesticides: Methods and Protocols, Methods in Molecular Biology, Vol. 1477. New York, NY: Springer Science+Business Media.

Glavic, P., Pintaric, Z. N., and Bogataj, M. (2021). Process design and sustainable development-a European perspective. Processes 9:148. doi: 10.3390/pr9010148

Gonçalves, A. L. (2021). The use of microalgae and cyanobacteria in the improvement of agricultural practices: a review on their biofertilising, biostimulating and biopesticide roles. Appl. Sci. 11:871. doi: 10.3390/app11020871

Hechelski, M., Waterlot, C., Dufrénoy, P., Louvel, B., Daïch, A., and Ghinet, A. (2021). Biomass of ryegrass from field experiments: toward a cost-effective and efficient biosourced catalyst for the synthesis of moclobemide. Green Chem. Lett. Rev. 14, 13-20. doi: 10.1080/17518253.2020.1856943

\section{ACKNOWLEDGMENTS}

We acknowledge the Centre for Oil-field Chemical Research for their facilities that made this publication lot easier.
Jessop, P. G., Trakhtenberg, S., and Warner, J. (2008). "The twelve principles of green chemistry," in ACS Symposium Series, 401-436. doi: 10.1021/bk-2009-1000.ch012

Kalpana, T., and Anil, K. (2021). A review of biopesticides and their plant phytochemicals information. Ann. Romanian Soc. Cell Biol. 25, 3576-3588.

Kharissova, O. V., Kharisov, B. I., Oliva González, C. M., Mendez, Y. P., and Lopez, I. (2019). Greener synthesis of chemical compounds and materials. R. Soc. Open Sci. 6:191378. doi: 10.1098/rsos.191378

Koulougliotis, D., Antonoglou, L., and Salta, K. (2021). Probing Greek secondary school students' awareness of green chemistry principles infused in context-based projects related to socio-scientific issues. Int. J. Sci Edu. 43, 1-16. doi: 10.1080/09500693.2020.186 7327

Kulkarni, M., Chaudhari, R., and Chaudhar, A. (2007). "Novel tension-active microbial compounds for biocontrol," in General Concepts in Integrated Pest and Disease Management, eds A. Ciancio and K. G. Mukerji (Dordrecht: Springer), 295-304.

Kumar, S. (2012). Biopesticides: a need for food and environmental safety. J. Biofertil. Biopestic. 3, 1-3. doi: 10.4172/2155-6202.1000e107

Leahy, J., Mendelsohn, M., Kough, J., Jones, R., and Berckes, N. (2014). "Biopesticide oversight and registration at the US Environmental Protection Agency," in Biopesticides: State of the Art and Future Opportunities, eds A. D. Gross, J. R. Coats, S. O. Duke, and J. N. Seiber (Washington, DC: ACS), 3-18.

Liu, X., Cao, A., Yan, D., Ouyang, C., Wang, Q., and Li, Y. (2019). Overview of mechanisms and uses of biopesticides. Int. J. Pest. Manag. 67, 65-72. doi: 10.1080/09670874.2019.1664789

Maciel, H., Zingaretti, S., and Maciel, G. (2014). Comparative analysis of the amino acid sequence of the Cry protein of codify the toxic protein to insects of the orders Lepidoptera, Diptera and Lepidoptera/Diptera. BMC Proc. 8, 120-120. doi: 10.1186/1753-6561-8-S4-P120

Manchikanti, P. (2019). "Bioavailability and environmental safety of nanobiopesticides," in Nano-biopesticides Today and Future Perspectives, ed O. Koul (London: Academic Press), 207-222.

Marrone, P. G. (2019). Pesticidal natural products-status and future potential. Pest. Manag. Sci. 75, 2325-2340. doi: 10.1002/ps.5433

Marteel-Parrish, A., and Newcity, K. M. (2017). Highlights of the impacts of green and sustainable chemistry on industry, Academia and Society in the USA Johnson Matthey Technol. Rev. 61, 207-221. doi: 10.1595/205651317X695776

McDougall, P. (2013). RङD Trends for Chemical Crop Protection Products and the Position of the European Market. A Consultancy Study Undertaken for ECPA. Available online at: https://croplifeeurope.eu/information-page/ regulatory-affairs/publications-regulatory-affairs

Mishra, J., Dutta, V., and Arora, N. K. (2020). Biopesticides in India: technology and sustainability linkages. 3 Biotech 10, 1-12. doi: 10.1007/s13205-020-02192-7

Nakasu, E. Y., Williamson, S. M., and Edwards, M. G. (2014). Novel biopesticide based on a spider venom peptide shows no adverse effects on honeybees. Proc. R. Soc. B Biol. Sci. 281:20140619. doi: 10.1098/rspb.2014.0619

Nuruzzaman, M., Liu, Y., Rahman, M. M., Dharmarajan, R., Duan, L., Uddin, A. F. M. J., et al. (2019). "Nanobiopesticides: composition and preparation methods," in Nano-Biopesticides Today and Future Perspectives, ed O. Koul (London: Academic Press), 69-131.

Panhwar, S., Buledi, J. A., Mal, D., Solangi, A. R., Balouch, A., and Hyder, A. (2021). Importance and analytical perspective of green synthetic strategies of copper, zinc, and titanium oxide nanoparticles and their applications in pathogens and environmental remediation. Curr. Anal. Chem. 17, 1-13. doi: 10.2174/1573411017999201125124513

Parker, K. M., and Sander, M. (2017). Environmental fate of insecticidal plant-incorporated protectants from genetically modified crops: knowledge 
gaps and research opportunities. Environ. Sci. Technol. 51, 12049-12057. doi: 10.1021/acs.est.7b03456

Pathma, J., Kennedy, R. K., Bhushan, L. S., Shankar, B. K., and Thakur, K. (2021). "Microbial biofertilizers and biopesticides: nature's assets fostering sustainable agriculture," in Recent Developments in Microbial Technologies (Singapore: Springer), 39-69.

Peralta, C., Sauka, D. H., Pérez, M., Onco, M. I., Fiodor, A., Ca-ballero, J., et al. (2021). Genome sequence analysis and insecticidal characterization of Bacillus thuringiensis Bt-UNVM_94, a strain showing dual insecticidal activity against Lepidopteran and Coleopteran pests. Proceedings. 65, 1-6.

Quarles, W. (2013). New biopesticides for IPM and organic production. IPM Pract. $33,1-20$.

Radwan, E. M., El-Malla, M. A., Fouda, M. A., and Mesbah, R. A. S. (2018). Appraisal of Positive Pesticides Influence on pink bollworm larvae, Pectinophora gossypiella (Saunders). Egyp. Acad. J. Biol. Sci. F. Toxicol Pest Control. 10, 37-47. doi: 10.21608/eajbsf.2018.17018

Rai, R., Singh, R. K., and Suthar, S. (2021). Production of compost with biopesticide property from toxic weed Lantana: quantification of alkaloids in compost and bacterial pathogen suppression. J. Hazard. Mater 401:123332. doi: 10.1016/j.jhazmat.2020.123332

Ram, K., and Singh, R. (2021). Efficacy of different fungicides and biopesticides for the management of lentil wilt (Fusarium oxysporum f. sp. Lentis). J. Agri. Search $8,55-58$.

Reddy, D. S., and Chowdary, N. M. (2021). Botanical biopesticide combination concept-a viable option for pest management in organic farming. Egypt. J. Biol. Pest. Control. 31, 1-10. doi: 10.1186/s41938-021-00366-w

Sadof, C. S., Mockus, L., and Ginzel, M. D. (2021). Factors influencing efficacy of an area-wide pest management program in three urban forests. Urban Forestry Urban Green. 58:126965. doi: 10.1016/j.ufug.2020.126965

Sarethy, I. P., and Saharan, A. (2021). Genomics, proteomics and transcriptomics in the biological control of plant pathogens: a review. Indian Phytopathol. 74, 3-12. doi: 10.1007/s42360-020-00302-2

Sarwar, A., Brader, G., Corretto, E., Aleti, G., Abaidullah, M., and Sessitsch, A. (2018). Qualitative analysis of biosurfactants from Bacillus species exhibiting antifungal activity. PLoS ONE 13:e0198107. doi: 10.1371/journal.pone.0198107

Sheldon, R. A. (2017). Metrics of green chemistry and sustainability: past, present, and future. ACS Sustain. Chem. Eng. 6, 32-48. doi: 10.1021/acssuschemeng.7b03505

Shingote, P. R., Moharil, M. P., and Dhumale, D. R. (2013). Distribution of vip genes, protein profiling and determination of entomopathogenic potential of local isolates of Bacillus thuringiensis. Bt Res. 4, 45-54.

Singh, K. D., Mobolade, A. J., Bharali, R., Sahoo, D., and Rajashekar, Y. (2021). Main plant volatiles as stored grain pest management approach: a review. J. Agric. Food Res. 4:100127. doi: 10.1016/j.jafr.2021.100127

Sparks, T. C., and Nauen, R. (2015). IRAC: Mode of action classification and insecticide resistance management. Pest. Biochem. Physiol. 121, 122-128. doi: 10.1016/j.pestbp.2014.1 1.014

Steinkraus, D. C., and Tugwell, N. P. (1997). Beauveria bassiana (Deuteromycotina: Moniliales) effects on Lygus lineolaris (Hemiptera: Miridae). J. Entomol. Sci. 32, 79-90. doi: 10.18474/0749-8004-32.1.79
Stevenson, P. C., Isman, M. B., and Belmain, S. R. (2017). Pesticidal plants in Africa: a global vision of new biological control products from local uses. Indus. Crops Products 110, 2-9. doi: 10.1016/j.indcrop.2017.08.034

Sujayanand, G. K., Sheelamary, S., and Prabhu, G. (2021). Recent innovations and approaches for insect pest management in agriculture. Biotica Res. Today 3, 100-102.

Sukumaran, N. P., and Gopi, S. (2021). "Overview of biopolymers: resources, demands, sustainability, and life cycle assessment modeling and simulation," in Biopolymers and Their Industrial Applications, eds S. Thomas, S. Gopi, and A. Amalraj (Amsterdam: Elsevier), 1-19. doi: 10.1016/B978-0-12-819240-5.00001-8

Tickner, J. A., Simon, R. V., Jacobs, M., Pollard, L. D., and van Bergen, S. K. (2021). The nexus between alternatives assessment and green chemistry: supporting the development and adoption of safer chemicals. Green Chem. Lett. Rev. 14, 21-42. doi: 10.1080/17518253.2020.1856427

Tijjani, A., Bashir, K. A., Mohammed, I., Muhammad, A., Gambo, A., and Habu, M. (2016). Biopesticides for pests control: a review. J. Biopest. Agric. 3, 6-13.

Trivedi, P., Mattupalli, C., Eversole, K., and Leach, J. E. (2021). Enabling sustainable agriculture through understanding and enhancement of microbiomes. New Phytol. 230, 2129-2147. doi: 10.1111/nph.17319

Tyagi, B., and Kumar, N. (2021). "Bioremediation: principles and applications in environmental management," in Bioremediation for Environmental Sustainability, eds G. Saxena, V. Kumar, and M. Shah (Elsevier), 3-28.

Verma, D. K., Guzmán, K. N. R., Mohapatra, B., Talukdar, D., Chávez-González, M. L., Kumar, V., et al. (2021). "Recent trends in plant-and microbe-based biopesticide for sustainable crop production and environmental security," in Recent Developments in Microbial Technologies, eds R. Prasad, V. Kumar, J. Singh, and C. P. Upadhyaya (Singapore: Springer), 1-37.

Vetter, S. H., Sapkota, T. B., Hillier, J., Stirling, C. M., Macdiarmid, J. I., Aleksandrowicz, L., et al. (2017). Greenhouse gas emissions from agricultural food production to supply Indian diets: implications for climate change mitigation. Agric. Ecosys. Environ. 237, 234-241. doi: 10.1016/j.agee.2016.12.024

Wattimena, M. A. C., and Latumahina, F. S. (2021). Effectiveness of botanical biopesticides with different concentrations of termite mortality. J. Belantara. 4, 66-74. doi: 10.29303/jbl.v4i1.630

Wei, J. Z., O’Rear, J., Schellenberger, U., Rosen, B. A., Park, Y. J., McDonald, M., et al. (2018). A selective insecticidal protein from Pseudomonas mosselii for corn rootworm control. Plant Biotechnol. J. 16, 649-659. doi: 10.1111/pbi.12806

Conflict of Interest: The authors declare that the research was conducted in the absence of any commercial or financial relationships that could be construed as a potential conflict of interest.

Copyright (c) 2021 Fenibo, Ijoma and Matambo. This is an open-access article distributed under the terms of the Creative Commons Attribution License (CC BY). The use, distribution or reproduction in other forums is permitted, provided the original author(s) and the copyright owner(s) are credited and that the original publication in this journal is cited, in accordance with accepted academic practice. No use, distribution or reproduction is permitted which does not comply with these terms. 